\title{
Computer-Based Two-Tier Diagnostic Test to Identify Critical Thinking Skills in Optical Instrument
}

\author{
Deka Maulidiansyah ${ }^{1, *}$ Inarsih Meutia ${ }^{1}$ Edi Istiyono ${ }^{2}$ \\ ${ }^{1}$ Master of Physics Education, Faculty of Mathematics and Natural Sciences, Universitas Negeri Yogyakarta, \\ Indonesia \\ ${ }^{2}$ Department of Educational Research and Evaluation, Graduate School, Universitas Negeri Yogyakarta, \\ Indonesia \\ *Corresponding author. Email: dekamaulidiansyah.2019@student.uny.ac.id
}

\begin{abstract}
This paper aims to determine the weaknesses of critical thinking skills and student responses to the use of google form as a medium for providing two-tier diagnostic tests to class XI students at SMA UII Yogyakarta on optical instrument material. The characteristics of the two-tier diagnostic test items used are valid and reliable. The research method used is descriptive qualitative. The subjects in this study were 20 students of class XI MIA at SMA UII Yogyakarta. The results of students' critical thinking skills on optical instrument material are in the medium category. Student responses to the use of google form as a medium computer based test for providing two-tier diagnostic tests to identify weaknesses in critical thinking skills are included in the high category.
\end{abstract}

Keywords: Critical thinking, Computer based test, Two-tier, Google form, Optical instrument

\section{INTRODUCTION}

Thinking skills in learning can determine the quality of student learning outcomes. Students not only develop low-level thinking skills (LOTS), but must develop higher-order thinking skills (HOTS). One of the goals of the global curriculum is to develop higher order thinking skills of students [1]. High-level skills are divided into 7 skills: (1) critical thinking (2) creativity (3) communication (4) career collaboration and independent learning (5) cross-cultural understanding and (6) computing / literacy [2]. Critical thinking skills can be used by students to solve problems faced, especially in learning physics. Critical thinking skills of students can evaluate statements, explain a thought, and can make decisions [3]. Critical thinking skills can be used to consider results and reconstruct thinking for the better [4].

Critical thinking skills can be measured by conducting an assessment. Assessment is used to find out the abilities or weaknesses of students. The purpose of assessment as a selection tool is a way of diagnosing strengths and weaknesses [5]. Assessment can be used to determine the purpose of the methods used in teaching and can provide guidance and guide them to overcome existing deficiencies [6].

Assessment using diagnostic tests can determine the abilities of students. Diagnostic tests are able to diagnose every attribute starting from reading, interpreting keywords, making conclusions from existing questions or statements [7]. A good diagnostic test can be used to provide information about misunderstandings, weaknesses, and how students think. Through diagnostic tests, information about basic abilities and learning difficulties can be obtained from students [8] and be able to find a deeper understanding of how learners think about answering questions even though their answers are wrong [9].

The questions on the diagnostic test can be in the form of reasoned multiple choice questions or what is commonly called a two-tier test. It aims to encourage students to express / choose reasons from the answers they choose for physics problems [10]. Multiple choice diagnostic tests are efficient, easy to use, and a person is less affected by certain multiple choice answers [11]. The identification of students' strengths or abilities is estimated to be more accurate using a two tier diagnostic instrument rather than a one tier 
diagnostic test. [12]. A reliable and valid measuring tool investigating student conceptual understanding and misconceptions can be developed two-tier tests [8].

During a pandemic like this time, the test can be carried out online via a website and in the form of a Computer Based Test (CBT). Online or computerbased tests have advantages, namely that they are easy to access, the results of these tests are immediately known, and are more efficient [13]. Assessment using Paper Based Test (PBT) is slowly being replaced by computer-based assessments [14]. Google form can be used to create CBT.

Google forms can be used as a forum for conducting surveys, providing quizzes, or collecting data quickly and more efficiently. For teachers, learning using Google Form is quite efficient and easy, both in terms of time, cost, and energy as a media for evaluation. For students, evaluating learning using google form media is also more interesting and fun [15]. Google forms also has its drawbacks. system efficiency and convenience of online test takers need to be considered when online tests are conducted [16]. The availability of a stable internet connection also needs attention [17].

The main of physics subjects used in this research is the subject matter of optical devices in class XI SMA/MA. Based on the results of questions and answers conducted on physics teachers in schools, the students felt that the optical instrument material was still difficult for students, for example in representing the description of the questions into image analysis and the difficulty in determining the relationship of the optical instrument in the problem. There are many difficulties in studying optical geometric materials, such as the concepts of reflection and refraction [18] and the formation of images from reflection and refraction events [19].

Identify weaknesses in critical thinking skills can use two-tier diagnostic test questions. Google form can be used as a media for giving test questions to students.

\section{METHOD}

This paper is a descriptive qualitative research. The instrument used was a two-tier diagnostic test to identify weaknesses in critical thinking skills with optical instrument. The test instrument consists of 8 two-tier or two-tier multiple choice questions arranged in google form. The question instrument used was valid and reliable and the google form instrument was validated by experts.
The validity of an instrument can be seen after the instrument has been assessed by an expert, and the results of the assessment are calculated using the Aiken's $\mathrm{V}$ formula. The validation results are calculated by the following equation:

$$
\mathrm{V}=\frac{\sum \mathrm{s}}{[\mathrm{n}(\mathrm{c}-1)]}
$$

Where $\mathrm{s}=\mathrm{r}-\mathrm{lo}, \mathrm{lo}=$ the lowest validity score (in this case 1 ), $c=$ highest validity rating (in this case 3 ), $\mathrm{r}=$ score given by the validator, $\mathrm{n}=$ number of validators, $\mathrm{V}=$ Aiken's V score. Aiken's V score is converted based on Table 1 .

Table 1. Product criteria

\begin{tabular}{|l|l|}
\hline Interval score & Criteria \\
\hline $0,8<\mathrm{V} \leq 1$ & Very Good \\
\hline $0,6<\mathrm{V} \leq 0,8$ & Good \\
\hline $0,4<\mathrm{V} \leq 0,6$ & Moderate \\
\hline $0,2<\mathrm{V} \leq 0,4$ & Low \\
\hline
\end{tabular}

Student scores can be categorized by changing them in percentage terms. The equation used to calculate the percentage of critical thinking skills can use the following equation:

$$
\bar{X}=\frac{\sum X}{n} \times 100 \%
$$

Where $\overline{\mathrm{X}}=$ score percentage, $\Sigma \mathrm{X}=$ score obtained, and $n=$ maximum score. Converting the results from the percentage analysis of students' critical thinking skills by using the categories in Table 2 [20].

Table 2. Rating category

\begin{tabular}{|c|l|}
\hline Result Percentage Range (\%) & Category \\
\hline $80 \leq x \leq 100$ & Very Good \\
\hline $60 \leq x<80$ & Good \\
\hline $40 \leq x<60$ & Moderate \\
\hline $20 \leq x<40$ & Low \\
\hline $0 \leq x<20$ & Very Low \\
\hline
\end{tabular}

The student response questionnaire consists of nine criteria that students must score from the google form media. To calculate the percentage of total score per item on student response data, the equation can be used:

$\mathrm{P}=\frac{\sum \mathrm{X}}{\sum \mathrm{X}_{\mathrm{i}}} \times 100 \%$ 
$\mathrm{P}=$ percentage of score, $\Sigma \mathrm{X}=$ the total score of each item, $\Sigma X_{\mathrm{i}}=$ the ideal number of scores. To calculate the percentage of the total response data students can use the following equation:

$\mathrm{P}_{\text {total }}=\frac{\sum \mathrm{P}}{\mathrm{n}}$

$\mathrm{P}_{\text {total }}=$ percentage of total responses, $\Sigma \mathrm{P}=$ total percentage of score, $\mathrm{n}=$ number of items / statements. The percentage result can be converted based on Table 3 [21].

Table 3. The percentage of students' responses

\begin{tabular}{|c|l|}
\hline Result Percentage Range (\%) & Category \\
\hline $80 \leq x \leq 100$ & Very Good \\
\hline $60 \leq x<80$ & Good \\
\hline $40 \leq x<60$ & Moderate \\
\hline $20 \leq x<40$ & Low \\
\hline $0 \leq x<20$ & Very Low \\
\hline
\end{tabular}

\section{RESULTS AND DISCUSSION}

\subsection{Results}

This study uses two-tier diagnostic test questions as shown in Figure 1 and google form as a medium for giving questions as shown in Figure 2.

Perhatikan gambar di bawah ini

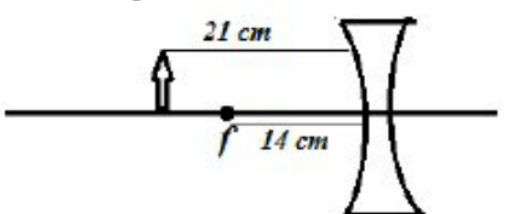

Berdasarkan gambar diperoleh hasil.

(1) Fokus bernilai positif

(2) Letak bayangan $8,4 \mathrm{~cm}$ di depan cermin

(3) Letak bayangan - $8,4 \mathrm{~cm}$ di depan cermin

(4) Sifat bayangan di perbesar

(5) Sifat bayangan diperkecil

Hasil yang benar adalah....

A. (1) dan (3)

B. (2) dan (4)

C. (3) dan (5)

D. (1) dan (4)

E. (2) dan (5)
Alasan....

A. Karena berada di depan lensa sehingga fokus lensa cekung bersifat positif

B. Kerena berada di belakang lensa sehingga fokus lensa cekung bersifat negative

C. Karena benda berada pada ruang kedua sehingga sifat bayangan diperbesar

D. Karena benda berada pada ruang kedua sehhingga sifat bayangan diperkecil

E. Karena benda berada didepan cermin sehingga bayangan bernilai positif

Figure 1 Two-tier diagnostic test questions

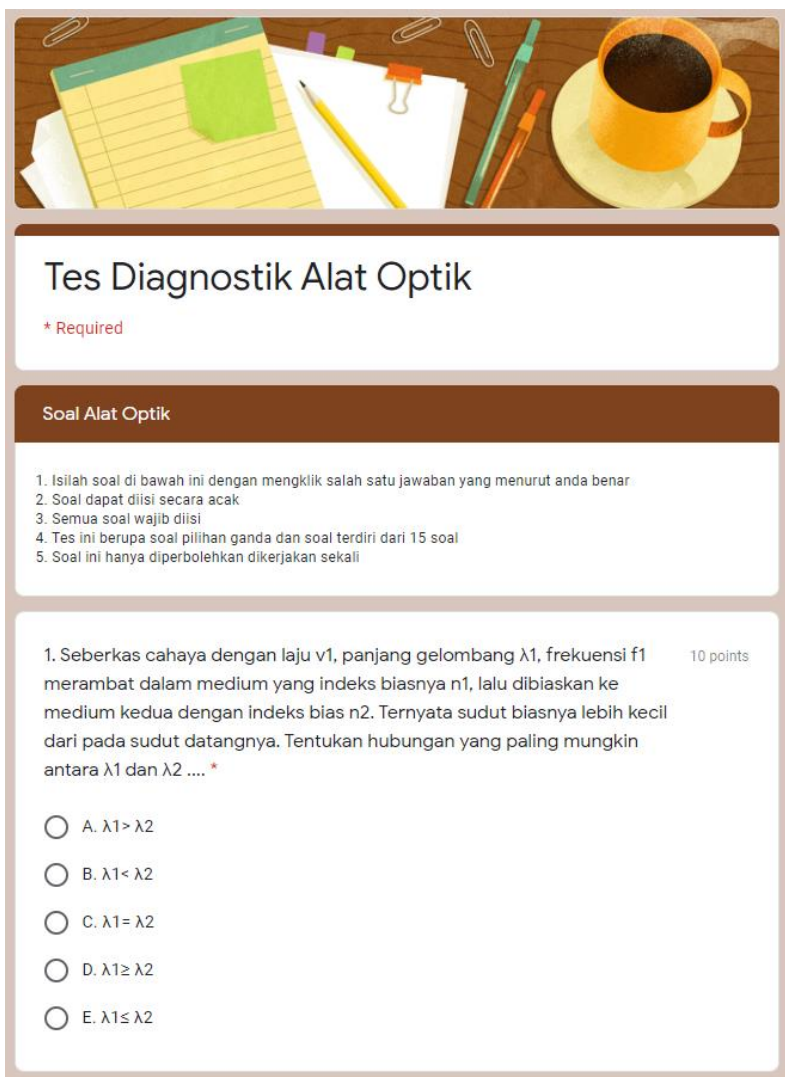

Figure 2 Google form

Data analysis on students' critical thinking skills on optical instrument can be seen in Table 4. The results of students' responses to google form media as a twotier diagnostic test media are in Table 5. 
Table 4. The results of the analysis of critical thinking skills

\begin{tabular}{|c|c|c|c|}
\hline Aspect & Critical Thinking Indicators & $\begin{array}{l}\text { Percentage of } \\
\text { Student Answers }\end{array}$ & Category \\
\hline \multirow{2}{*}{$\begin{array}{l}\text { Give a simple } \\
\text { explanation }\end{array}$} & $\begin{array}{l}\text { Identify / formulate questions based on events in } \\
\text { everyday life }\end{array}$ & $52,50 \%$ & Moderate \\
\hline & $\begin{array}{l}\text { Analyze statements and determine the similarities or } \\
\text { differences of a given event }\end{array}$ & $50,00 \%$ & Moderate \\
\hline \multirow[t]{2}{*}{$\begin{array}{l}\text { Build basic } \\
\text { skills }\end{array}$} & $\begin{array}{l}\text { Testing / examining sections that can be considered } \\
\text { to be trustworthy (or untrustworthy) based on the text } \\
\text { of the argument, advertisement, or experiment and its } \\
\text { interpretation, and provide reasons why }\end{array}$ & $42,50 \%$ & Moderate \\
\hline & $\begin{array}{l}\text { Consider the possibilities based on observations and } \\
\text { provide reasons }\end{array}$ & $42,50 \%$ & Moderate \\
\hline \multirow{2}{*}{ Conclude } & $\begin{array}{l}\text { Make specific conclusions by interpreting general } \\
\text { statements / conclusions }\end{array}$ & $47,50 \%$ & Moderate \\
\hline & $\begin{array}{l}\text { Make general conclusions by generalizing some } \\
\text { special events / statements }\end{array}$ & $45,00 \%$ & Moderate \\
\hline $\begin{array}{l}\text { Provide further } \\
\text { explanation }\end{array}$ & $\begin{array}{l}\text { Identify / consider a definition and identify further } \\
\text { assumptions / reasons }\end{array}$ & $35,00 \%$ & Low \\
\hline $\begin{array}{l}\text { Set strategy } \\
\text { and tactics }\end{array}$ & $\begin{array}{l}\text { Make decisions based on strategies and solutions } \\
\text { and formulate appropriate alternatives }\end{array}$ & $35,00 \%$ & Low \\
\hline
\end{tabular}

Table 5. Results of students' responses to google form

\begin{tabular}{|r|l|c|}
\hline No & Category & Percentage score \\
\hline 1 & The test display with google form is interesting & $90,00 \%$ \\
\hline 2 & The image in the test with google form is clear & $95,00 \%$ \\
\hline 3 & The image in the test with google form is easy to understand & $88,33 \%$ \\
\hline 4 & The use of language in the test with google form is easy to understand & $78,33 \%$ \\
\hline 5 & $\begin{array}{l}\text { The material in the test using google form is in accordance with the optical } \\
\text { instrument theme }\end{array}$ & $96,67 \%$ \\
\hline 6 & Test with google form is easily accessible & $95,00 \%$ \\
\hline 7 & The test with google form is practical to use & $91,67 \%$ \\
\hline 8 & General instructions for using the test using google form are clearly displayed & $85,00 \%$ \\
\hline 9 & $\begin{array}{l}\text { The test with google form can help find out skills and weaknesses in mastery of } \\
\text { optical instrument }\end{array}$ & $93,33 \%$ \\
\hline Total percentage score & $90,37 \%$ \\
\hline
\end{tabular}

\subsection{Discussion}

The weakness of critical thinking skills identified in this study was carried out in class XI MIA SMA UII Yogyakarta by using two-tier diagnostic test questions and using google form as the question-giving medium. The two-tier diagnostic test questions used have been validated and the results are valid. The reliability score of the two-tier diagnostic test item is 0.71 which can be said to be moderate [22].

Table 4 shows the results of the analysis of the aspects of critical thinking skills of class XI SMA UII Yogyakarta. In the aspect of providing a simple explanation, there are two indicators. In the first indicator, the results are $52.50 \%$ in the medium category, meaning that some students can formulate questions in the bending of light. In the second indicator, the results are $50.00 \%$ in the moderate category, meaning that students can analyze statements in the relationship between the refractive index to the angle come and bias angle. These results indicate that some students can provide simple explanations for the problems of the questions given.

In the aspect of building basic skills, there are two indicators. In the first indicator, the results are $42.50 \%$ in the medium category, meaning that some students can test the image formation experiment on the lens. In the second indicator, the result is $42.50 \%$ with a moderate category, meaning that some students can consider observations in visual disturbances. These results indicate that some students can build basic skills based on arguments and observations.

In the concluding aspect, there are two indicators. In the first indicator, the result is $47.50 \%$ in the medium category, which means that some students can make special conclusions in the reflection on a flat 
mirror. In the second indicator, the results get $45.00 \%$ in the medium category, which means that some students can make general conclusions in the process of entering light into the eye.

In the aspect of providing further explanation, the indicator gets a result of $35.00 \%$ with a low category meaning that most students cannot identify assumptions about deflection of light.

In the aspect of managing strategies and tactics, the indicator gets a result of $35.00 \%$ with a low category meaning that most students cannot make decisions based on strategies and solutions in shadow formation.

In this study using questions that have been validated. Based on table 4 , it can be seen that the critical thinking skills of students in optical material are still classified as moderate, with an average of $43.75 \%$. The abilities possessed by students are still in this category because students are less in analyzing a problem and less in concluding a problem. Students usually do not go through analytical steps to solve problems [23].

Based on the data obtained from the data processing that has been done, it shows that the critical thinking abilities of students are classified as moderate or moderate. This is influenced by several factors, including the learning methods used by the teacher, the facilities and learning resources used, and the motivation and readiness of students in the learning process.

The media used in this study is a google form as shown in Figure 1. The use of google form aims to facilitate data collection, filling in questions and students can find out the answers and test results immediately after working on the test. The validation results of the google form media which are used as a forum for giving questions to students are in the form of Aiken's V score of 1. This score states that google form media is very good to be given for computerbased test media (CBT).

The results of the questionnaire responses of students to the Google Form media also showed a very high percentage score of $90.37 \%$. This score states that students who use google form media can clearly understand and use it. For students, evaluating learning using google form media is also more interesting and fun. Learning evaluation conducted using google form media is suitable for use as a learning evaluation media [15]. This research can be developed by using the results as a research background to improve the critical thinking skills of students.

\section{CONCLUSION}

The critical thinking skills of students at SMA UII Yogyakarta class XI are in the moderate category on optical instrument. Based on the research results, the highest critical thinking skills in the aspect of providing simple explanations. The lowest critical thinking skills are in the aspect of providing further explanation and arranging strategies and tactics. Student responses were very high towards the use of google forms in identifying critical thinking skills using a two-level diagnostic test. A two-level diagnostic test using google form can be used to identify students' critical thinking skills.

\section{REFERENCES}

[1] T.S. Yen, S.H. Halili, Effective Teaching of Higher-Order Thinking (HOT) in Education, The Online Journal of Distance Education and eLearning 3(2) (2015) 41-47.

[2] I.W. Widana, Higher Order Thinking Skills Assessment (HOTS), Journal of Indonesian Student Assessment and Evaluation 3(1) (2017) 32-44.

[3] F.H. Sutrisno, S.K. Handayanto, E. Supriyana, R. Laksmisari, How Does The Students' Critical Thinking Ability In Geometry Optics?, Unnes Science Education Journal 7(2) (2018) 186-191. DOI: https://doi.org/10.15294/usej.v7i2.24297

[4] B. Judge, P. Jones, E. McCreery, Critical Thinking Skills for Education Students, Learning Mater, 2009.

[5] N. Ahmed, S. Senam, A. Wiyarsi, Assessment Instrument for Practicum Skills in Trimyristin Separation for Undergraduate Students, Jurnal Inovasi Pendidikan IPA 5(1) (2019) 89-97. DOI: https://doi.org/10.21831/jipi.v5i1.24515

[6] J.A. Asfaroh, D. Rosana, Supahar, Development of the evaluation instrument use cipp on the implementation of project assessment topic optik, in: Cite as: AIP Conference Proceedings, vol. 1868, AIP Publishing, Maryland, 2017, pp. 1-9. DOI: https://doi.org/10.1063/1.4995190

[7] D. Gurcay, E. Gulbas, Development of ThreeTier Heat, Temperature and Internal Energy Diagnostic Test, Research in Science and Technological Education 33(2) (2015) 197-217. DOI: https://doi.org/10.1080/02635143.2015.101815 4 
[8] E. Taşlidere, Development and Use of A ThreeTier Diagnostic Test to Assess High School Students' Misconceptions About The Photoelectric Effect, Research in Science and Technological Education 34(2) (2016) 1-23. DOI:

https://doi.org/10.1080/02635143.2015.112440 $\underline{9}$

[9] A.M.R. Tumanggor, Supahar, H. Kuswanto, E.S. Ringo, Using four-tier diagnostic test instruments to detect physics teacher candidates' misconceptions: Case of mechanical wave concepts, in: Journal of Physics: Conference Series, vol. 1440, IOP Publishing, Bristol, 2020, pp. 1-8. DOI: https://doi.org/10.1088/1742$\underline{6596 / 1440 / 1 / 012059}$

[10] P. Barniol, G. Zavala, Mechanical Waves Conceptual Survey: Its Modification and Conversion to A Standard Multiple-Choice Test, Physical Review Physics Education Research 12(010107) (2016) 1-12. DOI: https://doi.org/10.1103/PhysRevPhysEducRes.1 $\underline{2.010107}$

[11] I.S. Caleon, R. Subramaniam, Do Students Know What They Know and What They Don't Know? Using a Four-Tier Diagnostic Test to Assess the Nature of Students' Alternative Conceptions, Research in Science Education 40(3) (2009) 313-337. DOI: https://doi.org/10.1007/s11165-009-9122-4

[12] H.O. Arslan, C.Cigdemoglu, C. Moseley, A Three-Tier Diagnostic Test to Assess PreService Teachers' Misconceptions About Global Warming, Greenhouse Effect, Ozone Layer Depletion, and Acid Rain, International Journal of Science Education 34(11) (2012) 1667-1686. DOI:

https://doi.org/10.1080/09500693.2012.680618

[13] D. Maulidiansyah, H.T.M. Silitonga, Hamdani, Pengembangan Tes Diagnostik Menggunakan Aplikasi Google Form Materi Momentum dan Impuls untuk Siswa SMA, Jurnal Pendidikan dan Pembelajaran Khatulistiwa 7(7) (2018) 1-9.

[14] E. Istiyono, Computer adaptive test as the appropriate model to assess physics achievement in 21st century, in: Advances in Social Science, Education and Humanities Research, vol. 178, Atlantis Press, Paris, 2018, pp. 304-309. DOI: https://doi.org/10.2991/icoie-18.2019.67
[15] D. Purwati, A.N.P. Nugroho, Pengembangan Media Evaluasi Pembelajaran Sejarah Berbasis Google Formulir di SMA N 1 Prambanan, ISTORIA Jurnal Pendidikan dan Ilmu Sejarah 14(1) (2018) 1-10. DOI: https://doi.org/10.21831/istoria.v14i1.19398

[16] N. A. Karim, Z. Shukur, Computers in human behavior proposed features of an online examination interface design and its optimal values, in: Computers in Human Behavior, vol. 64, Elsevier, Amsterdam, 2016, pp. 414-422. DOI: https://doi.org/10.1016/j.chb.2016.07.013

[17] A. Z. Mansor, Managing students' grades and attendance records using google forms and google spreadsheets, in: Procedia - Social and Behavioral Sciences, vol. 59, Elsevier, Amsterdam, 2012, pp. 420-428. DOI: https://doi.org/10.1016/j.sbspro.2012.09.296

[18] S. Aydin, P.U. Keleş, M.A. Haşiloğlu, Establishment for Misconceptions that Science Teacher Candidates Have About Geometric Optics, The Online Journal of New Horizons in Education 2(3) (2012) 7-17.

[19] H. Chang, J. Chen, C. Guo, C. Chen, C. Chang, S. Lin, W. Su, K. Lain, S. Hsu, J. Lin, C. Chen, Y. Cheng, L. Wang, Y. Tseng, Investigating Primary And Secondary Students' Learning Of Physics Concepts in Taiwan, International Journal of Science Education 29(4) (2007) 465482.

DOI: https://doi.org/10.1080/09500690601073210

[20] E. P. Widoyoko, Technique for Developing Research Instruments, Pustaka Pelajar, 2013.

[21] Riduwan, Methods and Techniques for Compiling a Thesis, Alfabeta, 2010.

[22] I. Megawati, Pengembangan Tes Higher Order Thinking Skills (HOTS) Bloomian menggunakan Computer Adaptive Tes (CAT) dalam Mata Pelajaran Fisika Kelas X SMA, ePrints@UNY, 2017, Accessed on: Oct.2020, [Online]. Available: https://eprints.uny.ac.id/49081/

[23] S.Y. Seventika, Y.L. Sukestiyarno, S. Mariani, Critical thinking analysis based on Facione (2015) - Angelo (1995) logical mathematics material of vocational high school (VHS), in: Journal of Physics: Conference Series, vol. 983, IOP Publishing, Bristol, 2018, pp. 1-6. DOI: https://doi.org/10.1088/1742$\underline{6596 / 983 / 1 / 012067}$ 